\title{
THE POTENTIAL IMPACT OF CLIMATE CHANGE ON HURGHADA CITY, EGYPT, USING TOURISM CLIMATE INDEX
}

\author{
Dalia MAHMOUD* \\ Cairo University, Faculty of Urban and Regional Planning, Department of Environmental \\ Planning, 1 Gamaa Street, Giza, Egypt, 12613, e-mail: daliaelnahry@cu.edu.eg \\ Gamil GAMAL \\ Cairo Univeristy, Faculty of African Postgraduate Studies, Department of Natural \\ Resources, 1 Gamaa Street, Giza, Egypt, 12613, e-mail: gamil.gamal@cu.edu.eg \\ Tarek ABOU EL SEOUD \\ Cairo University, Faculty of Urban and Regional Planning, Department of Environmental \\ Planning, 1 Gamaa Street, Giza, Egypt, 12613, e-mail: Tarek.Seoud@cu.edu.eg
}

Citation: Mahmoud, D., Gamal, G., \& Abou El Seoud, T. (2019). THE POTENTIAL IMPACT OF CLIMATE CHANGE ON HURGHADA CITY, EGYPT, USING TOURISM CLIMATE INDEX. GeoJournal of Tourism and Geosites, 25(2), 496-508. https://doi.org/10.30892/gtg.25218-376

\begin{abstract}
Tourism is one of the leading sources of income, crucial to Egypt's economy where it contributes more than $7.2 \%$ of GDP and $14.4 \%$ of foreign currency revenues. The objective of the research is to investigate the impacts of climate change on tourism sector and expecting the future tourism performance of cities. The research has chosen Hurghada, the leading attracting coastal city on the Red Sea for foreign tourist as a case study. The mean monthly data of temperature, rainfall, moisture, wind speed and sun radiation derived by the regional climate model developed by the Swedish Meteorological and Hydrological Institute (SMHIRCA35) for the two climate change scenarios of the Intergovernmental Panel on Climate Change (IPCC) RCP4.5 and RCP8.5 used to achieve this objective. These data used for Hurghada climate zone for the future time period of 2005-2050. The impacts of the RCP4.5 and RCP8.5 scenarios on Hurghada tourism sector will be estimated based on the application of the Tourism Climatic Index (TCI) that is widely used for the adaptation measure of the climatic suitability for tourism, which examines potential changes in climatic attractiveness of destinations, through the statistical analysis of existing and forecasting meteorological parameters. The research methodology on Hurghada shows a major change expectation in tourism seasons behavior and that climate change will play a major role in changing the climatic seasonal Hurghada tourism performance. The research recommends proactive adaptation strategies rather than reactive policy towards climate change to achieve sustainability and climate change resilience of Hurghada city.
\end{abstract}

Keywords: climate change, tourism, Tourism Climate Index, regional climate model, Hurghada

\footnotetext{
* Corresponding author
} 


\section{INTRODUCTION}

Tourism is one of the main economic sectors in Egypt; it contributes to increasing Gross domestic product (GDP) and raising economic growth rates (CAPMAS, 2017). The total contribution of tourism and travel to GDP was 194.8 billion Egyptian pound (EGP), 7.2\% of GDP in 2016 and is forecast to rise by $6.1 \%$ pa to 355.6 billion EGP, $8.9 \%$ of GDP in 2027 (WTTC, 2017). The total number of tourists coming from all over the world was 8.3 million in 2017 (CAPMAS et al., 2018). Egypt has long been known throughout its history as a popular tourist destination, with different types of tourism, its geographical location and mild climate during the summer and winter. It has many important tourist cities such as Sharm el-Sheikh, Hurghada and Luxor (Egyptian Ministry of Foreign Affairs, 2019). The general climate of Egypt is a desert climate, a hot climate in the summer and mild in the winter. During the summer season (June-August), the climate is hot and dry all over Egypt. While in the winter season (December-February), in northern Egypt climate is mild with some rainfall, mainly on coastal areas, while the climate in the south is practically rainless with warm sunny days and cool nights (Tolba et al., 2016).

Tourism is strongly influenced by climate and weather (Hosseini et al., 2015), both of which have a significant impact on the tourism industry, affecting the timing and length of the tourism seasons and the selection of destinations by tourists (Scott et al., 2004) as climatic conditions impact tourism activities such as sight-seeing (Gomez Martin, 2005). With global warming changes are occurring at an unprecedented rate in the earth's climate variables such as temperatures and precipitation (Solomon et al., 2007). The global temperature change at the end of the $21^{\text {st }}$ century is expected to exceed $1.5-2{ }^{\circ} \mathrm{C}$ of the period (1850-1900) in Representative concentration pathways (RCP) scenarios (Stocker et al., 2013). The expected rise in temperature will lead to a shift in the attractive areas of tourism towards the areas with the most suitable temperature. In terms of Egypt, a decline in the number of tourists visiting the country is projected at about $20 \%$ by the year 2060, which negatively affects tourism revenues by 13-17 billion EGP per year (Smith et al., 2013). Coral reefs in the Red Sea are already declining because of higher temperatures of water and are estimated to stop growing by 2070 (Cantin et al., 2010).

Tourism destinations must adapt to the direct effects of climate change, such as rising temperatures and secondary effects such as sea level rise and the decrease of snow cover (Rossello-Nadal, 2014). As the relationship between tourism and climate is very complex this has led to the need to assess the suitability of the climate for tourism (Bakhtiari et al., 2013). It is argued that an index approach is useful for understanding this complexity because of the overlapping nature of weather, and the difficult ways in which weather variables combine to reflect the results that benefit tourism by determining the appropriate climate for tourism (De Freitas et al., 2008). Tourism Climate Index (TCI) has a world-wide application in numerous geographical locations for example in Ethiopia (Behaylu \& Teshome, 2018), China (Fang \& Yin, 2015), Lake Balaton region in Hungary (Németh, 2013) also for Iran (Gandomkar et al., 2011; Farajzadeh \& Matzarakis, 2009; Gourabi \& Palic, 2012). The Tourism Climate Index includes several climatic variables that are combined in a mathematical formula to provide human comfort levels; the impacts of climate change on the tourism industry can be predicted by linking climate change scenarios and changes in human comfort levels (Bakhtiari et al., 2018; Roshan et al., 2016; Kubokawa et al., 2014; RosselloNadal, 2014). Climate indices help tourism planners and marketing agents to plan and manage tourism by anticipating off-peak periods to develop tourism promotion programs for that period and expect the busy peak times to determine the development programs required to meet them. Tourists can take advantage of climate indicators to choose the best tourist destinations and the timing of their vacation (Bakhtiari et al., 
2013). The main objective of this paper is assessing the influences of climate change on the tourism sector in the Egyptian environment to guide the adaptation and mitigation strategies to plan and develop the tourism industry in Egypt to face these effects by using one of the climate indexes. A tourism climate index is applied for the first time to the city of Hurghada, one of the most popular tourism cities in Egypt in order to determine the suitable months for tourism in the city. This analysis helps towards taking appropriate adaptation and mitigation strategies for the specificity of the situation in order to correct planning, attract tourists, and develop the local tourism industry to face future climate changes and expected increase temperatures.

\section{MATERIALS AND METHODS}

\section{Target Area}

Hurghada is the administrative capital of the Red Sea Governorate (Figure 1). The city is located on the western shore of the Red Sea on a longitude $48^{\prime} 33^{\circ} \mathrm{E}$ and latitude $15^{\prime} 27^{\circ} \mathrm{N}$. It is bordered from the north by Ras Gharib city, from the south by Safaga, from the east by the coast of the Red Sea and from the west by the mountains of the Red Sea.

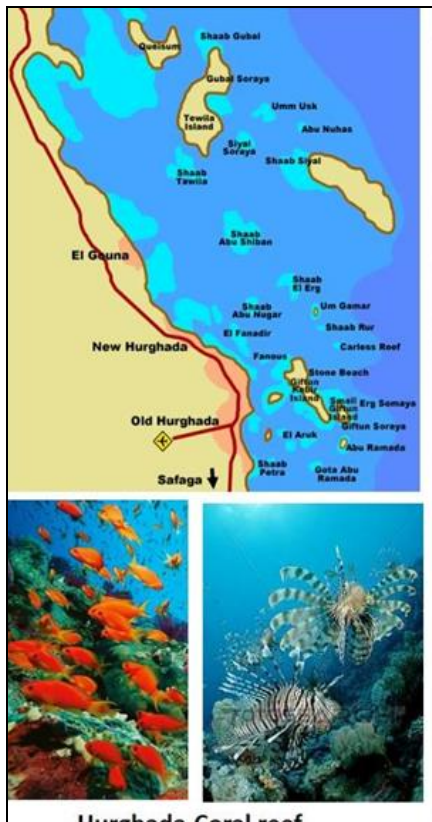

Hurghada Coral reef

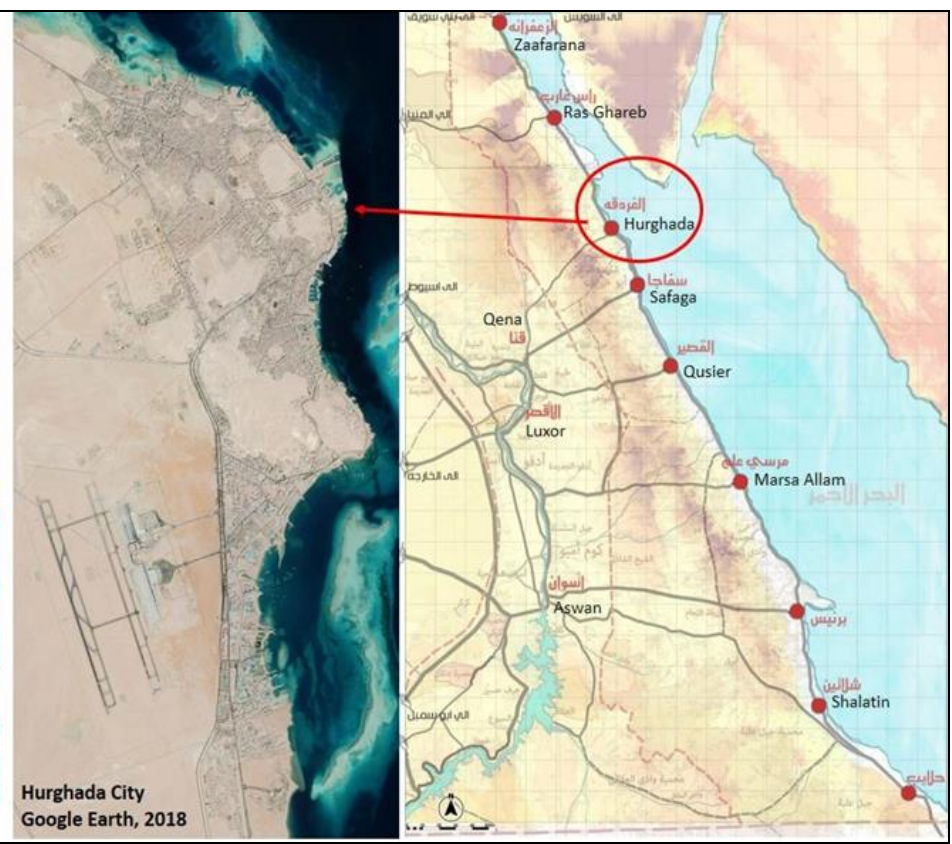

Google Earth, 2018

Figure 1. Location of Hurghada city (Source: Google Earth 2018)

Hurghada has a mild climate throughout the year (Figure 2); its dry desert climate leads to differences in temperature between day and night, which is hot in the day and cold at night especially during the winter months. Temperature can reach highs of $42{ }^{\circ} \mathrm{C}$ and lows of $18{ }^{\circ} \mathrm{C}$ (Egypt's Tourism Authority, 2019). Hurghada offers all possibilities for fishing, underwater fishing and snorkelling because of the clarity of its water and the worldwide fame of its coral reefs and rare marine life (Figure 1) (Egypt's State Information Service, 2019). Although it is rated one of the three best diving areas in the world, it is a popular destination also for non-divers. Leisure on the beach, water sports, clubbing and golfing are just a few of the options to choose from it in addition to Hurghada's health resorts (Egyptian Tourism Authority, 2019). 


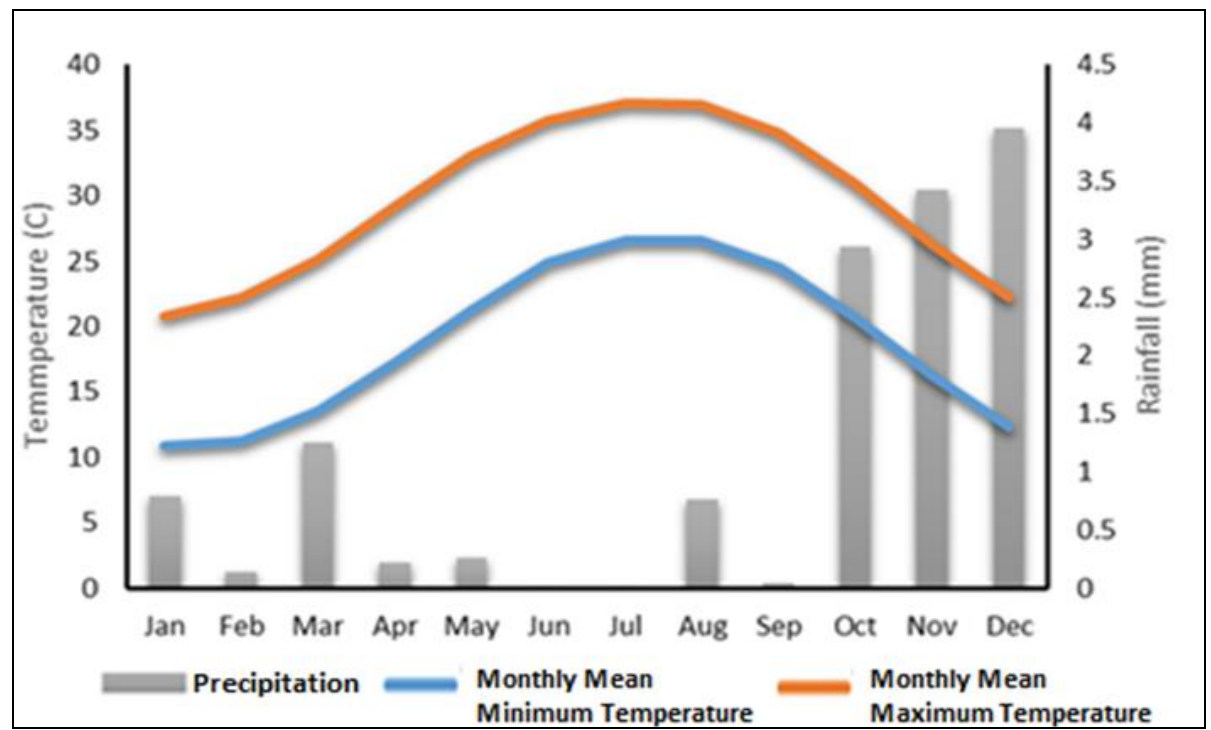

Figure 2. Mean climate of Hurghada for the period (1952-2005)

(Source: Egyptian Meteorological Authority, 2019 edited by Author)

\section{Data}

To progress suitable adaptation strategies at global, regional and local scale, the information about probable future influences of climate change under global warming is becoming essential. The main source of such info is state-of-the-art Atmosphere - Ocean Global Climate Models (AOGCMs), which simulate possible climate change under a variety of future greenhouse gas emission or concentration scenarios. During the last few years 20 climate modelling groups using more than 50 GCM models have contributed in the Coupled Model Intercomparison Project phase 5 (CMIP5), creating a great multimodel ensemble of climate change simulations (Taylor et al., 2012).

While the difficulty and resolution of AOGCMs are both growing, computational difficulties still limit the use of high-resolution AOGCMs for producing large ensembles of long multi-century climate simulations. The horizontal resolution in $\mathrm{CMIP}_{5}$ is vary between $100-250 \mathrm{~km}$, which is not enough to make available climate change information on the regional to local scale. Also long-term predictions, till the end of this century, AOGCMs are progressively being used for estimates on more near-future, decadal time scales (Meehl et al., 2014; Gonzalez \& Goddard, 2016). The Coordinated Regional Climate Downscaling Experiment (CORDEX) (Giorgi et al., 2009; Jones et al., 2011), recognized in 2009 and reinforced by the World Climate Research Programme (WCRP), goals to fill such gaps by handling international efforts in regional climate downscaling giving predefined grids, experiment procedures, output setups, and variables. One of the core purposes of CORDEX is to make regional climate simulations simply and flexibly accessible for end-user groups at regional and local levels.

Representative Concentration Pathways (RCPs) Scenarios that include time series of emissions and concentrations of the full suite of greenhouse gases (GHGs) and aerosols and chemically active gases, as well as land use/land cover (Moss et al., 2008). The word representative signifies that each RCP provides only one of many possible scenarios that would lead to the specific radiative forcing characteristics. The term pathway emphasizes that not only the long-term concentration levels are of interest, but also the trajectory taken over time to reach that outcome (Moss et al., 2010). Four RCPs produced from 
Integrated Assessment Models and are used in the present IPCC Assessment as a basis for the climate predictions and projections presented in WGI AR5 Chapters 11 to 14 (IPCC, 2013); which are RCP2.6, RCP4.5, RCP6.o and RCP8.5. only two scearios used in this study, RCP4.5 which is the intermediate stabilization pathways in which radiative forcing is stabilized at approximately $4.5 \mathrm{~W} / \mathrm{m} 2$ and $6.0 \mathrm{~W} / \mathrm{m} 2$ after 2100 , and RCP8.5 scenario is the high pathway for which radiative forcing reaches $>8.5 \mathrm{~W} / \mathrm{m} 2$ by 2100 and continues to rise for some amount of time (Van Vuuren et al., 2011; Pachauri et al., 2014).

Table 1. Monthly value of each indicator in Hurghada for the different three periods (Source: Egyptian Meteorological data and CORDEX data)

\begin{tabular}{|c|c|c|c|c|c|c|c|c|c|c|c|c|c|c|}
\hline Var & & eriods & 疗 & 空 & 总 & $\frac{1}{2}$ & 空 & 昰 & 窝 & 导 & 茨 & છ & $\begin{array}{l}3 \\
0 \\
z\end{array}$ & 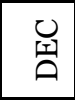 \\
\hline \multirow{4}{*}{$\begin{array}{c}\text { Maximum } \\
\text { Temperature } \\
\left({ }^{\circ} \mathrm{C}\right)\end{array}$} & \multicolumn{2}{|c|}{$1952-1975$} & 21 & 21.6 & 23.8 & 26.7 & 30 & 32.2 & 33 & 33.3 & 31.2 & 29.1 & $25 \cdot 9$ & 22.5 \\
\hline & \multicolumn{2}{|c|}{ 1976-2005 } & \begin{tabular}{|l|}
21.5 \\
\end{tabular} & 22.5 & \begin{tabular}{|l|}
25.1 \\
\end{tabular} & 29.1 & 33 & $35 \cdot 3$ & 36.4 & 36.3 & 34.3 & 31.1 & 26.9 & 23 \\
\hline & \multirow{2}{*}{ 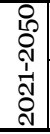 } & $\mathrm{RCP} 4.5$ & \begin{tabular}{|l|}
21.9 \\
\end{tabular} & 23.4 & 27.1 & 31.5 & 34.9 & 37.9 & 40.1 & 39.7 & 36.9 & 32.5 & 27.0 & 23.0 \\
\hline & & RCP8.5 & 21.97 & 23.7 & 27.1 & 31.1 & $35 \cdot 3$ & 38.7 & 40.2 & 40.1 & 37.4 & 32.8 & 27.1 & 22.8 \\
\hline \multirow{4}{*}{$\begin{array}{c}\text { Average } \\
\text { Temperature } \\
\left({ }^{\circ} \mathrm{C}\right)\end{array}$} & \multicolumn{2}{|c|}{$1952-1975$} & 15.7 & 16.6 & 19 & 22.5 & 25.8 & 28.7 & 29.6 & 30 & 27.9 & 25 & 20.9 & 17 \\
\hline & \multicolumn{2}{|c|}{ 1976-2005 } & 16 & 17 & \begin{tabular}{|l|}
19.8 \\
\end{tabular} & 23.7 & 27.8 & 30.5 & 31.8 & 31.6 & 29.5 & 26.1 & 21.6 & \begin{tabular}{|l|}
17.6 \\
\end{tabular} \\
\hline & 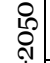 & $\mathrm{RCP} 4.5$ & 17.11 & 18.0 & 21.1 & 24.9 & 28.6 & 32.0 & 34.3 & 34.0 & 31.7 & 27.4 & 22.2 & 18.5 \\
\hline & จे & $\mathrm{RC}$ & $17 \cdot 31$ & 18.3 & 21.1 & 24.8 & 29.0 & 32.6 & 34.5 & 34.4 & 32.2 & 27.7 & 22.7 & 18.4 \\
\hline \multirow{4}{*}{$\begin{array}{c}\text { Average } \\
\text { Relative } \\
\text { Humidity } \\
\text { (\%) }\end{array}$} & \multicolumn{2}{|c|}{$1952-1975$} & 51 & 49 & 49 & 47 & 44 & 43 & 47 & 47 & 51 & 55 & 54 & 54 \\
\hline & \multicolumn{2}{|c|}{ 1976-2005 } & 48.3 & 44.2 & 42.2 & 37.7 & 32.8 & 31.8 & 34.5 & 36.7 & 40.7 & 47 & 49.2 & 49.9 \\
\hline & 站 & $\mathrm{RCP} 4.5$ & 55.8 & 54.9 & 49.4 & 43.9 & 35.6 & 31.1 & 30.6 & 33.5 & 39.9 & 51.4 & 56.8 & 6.7 \\
\hline & ลे & RCP8.5 & 5.88 & 54.1 & 50.1 & 44.1 & 33.9 & 29.9 & 30.6 & 33.9 & 39.8 & 51.4 & 55.8 & 55.6 \\
\hline \multirow{4}{*}{$\begin{array}{l}\text { Minimum } \\
\text { Relative } \\
\text { Humidity } \\
(\%)\end{array}$} & \multicolumn{2}{|c|}{ 1952-1975 } & 34.35 & 31.0 & 28.1 & 24.5 & 18.9 & 16.4 & 18.4 & 21.8 & 23.8 & 31.1 & 35.4 & 35.7 \\
\hline & \multicolumn{2}{|c|}{ 1976-2005 } & 33.36 & 31.1 & 28.3 & 25.1 & 20.0 & 16.3 & 17.7 & 20.1 & 23.1 & 31.0 & 36.4 & 36.3 \\
\hline & : & $\mathrm{RCP} 4.5$ & 33.71 & 31.4 & 26.4 & 23.9 & 19.0 & 16.7 & $\mid$\begin{tabular}{|l|}
17.2 \\
\end{tabular} & 19.1 & 23.5 & 30.0 & 34.0 & 35.5 \\
\hline & ลี่ & $\mathrm{R}$ & 43 & 30.8 & 27.0 & 24.3 & 17.9 & 5.9 & 17.3 & 19.5 & 23.6 & 30.3 & 34.7 & 34.9 \\
\hline \multirow{4}{*}{$\begin{array}{l}\text { Sunshine } \\
\text { (hrs/day) }\end{array}$} & \multicolumn{2}{|c|}{ 1952-1975 } & 8.92 & 9.61 & 10.5 & 11.2 & 11.8 & 12.0 & 11.9 & 11.4 & 10.7 & 9.90 & 9.11 & 8.71 \\
\hline & \multicolumn{2}{|c|}{\begin{tabular}{l|l}
$1976-2005$ \\
\end{tabular}} & 8.92 & 9.60 & 10.4 & 11.2 & 11.8 & 12.0 & 11.9 & 11.4 & 10.7 & 9.88 & 9.11 & 8.68 \\
\hline & 员 & $\mathrm{RCP} 4.5$ & 8.93 & 9.59 & 10.5 & 11.2 & 11.8 & 12.0 & 11.9 & 11.4 & 10.7 & 9.88 & 9.14 & 70 \\
\hline & 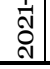 & RCP8.5 & 8.93 & 9.62 & 10.5 & 11.2 & $\mid 11.8$ & 12 & 11.9 & 11.4 & 10.7 & 9.88 & 9.12 & 8.72 \\
\hline \multirow{4}{*}{$\begin{array}{c}\text { Precipitation } \\
(\mathrm{mms})\end{array}$} & \multicolumn{2}{|c|}{ 1952-1975 } & 0.2 & 0.4 & 0.4 & 0.2 & 0.4 & 0 & 0 & 0 & 0 & 0.2 & 0.3 & 1.5 \\
\hline & \multicolumn{2}{|c|}{ 1976-2005 } & 1.4 & 0.2 & 2 & $\mathrm{O}$ & 0.3 & $\mathrm{O}$ & O & $\mathrm{O}$ & $\mathrm{O}$ & 4.9 & 3.21 & 7.2 \\
\hline & 足 & $\mathrm{R}$ & 18 & 24 & 21 & 1.57 & 21 & 0 & 0 & o & 1.05 & 1.55 & .46 & 0.96 \\
\hline & ลें & RCP8.5 & 0.33 & 0.05 & 0.28 & 1.03 & 0.28 & 0.01 & 0.01 & o & 0.89 & 1.79 & 1.22 & 0.58 \\
\hline \multirow{4}{*}{$\begin{array}{l}\text { Wind } \\
(\mathrm{km} / \mathrm{h})\end{array}$} & \multicolumn{2}{|c|}{ 1952-1975 } & 20.93 & 22.6 & 23.5 & 22.9 & 24.6 & 26.5 & 23.9 & 23.9 & 25.2 & 20.93 & 19.08 & 19.82 \\
\hline & \multicolumn{2}{|c|}{ 1976-2005 } & 21.30 & 22.0 & 22.4 & 22.4 & 23.3 & 27.8 & 25.2 & 25.9 & 26.3 & 22.41 & 20.93 & 20.93 \\
\hline & \multirow{2}{*}{$\begin{array}{l}0 \\
0 \\
0 \\
1 \\
0 \\
0 \\
0\end{array}$} & $\mathrm{RCP} 4.5$ & 90 & 15.2 & 15.6 & 14.9 & 16.6 & 22.2 & 24.1 & 22.5 & 20.1 & 14.9 & 14.1 & 14.9 \\
\hline & & RCP8.5 & 15.34 & $15 \cdot 5$ & $15 \cdot 3$ & 15.2 & 18.0 & 22.2 & 23.9 & 22.7 & 20.6 & 14.9 & 14.8 & 14.8 \\
\hline
\end{tabular}


To investigate the annual variation and projected changes in TCI scores for Hurghada city, monthly mean climate data were obtained from the Egyptian Meteorological Authority for the historical period (1952 - 2005).

The future climate conditions are analyzed using the regional climate model developed by the Swedish Meteorological and Hydrological Institute (SMHI-RCA35) (Samuelsson et al., 2011), whith grid size $0.5^{\circ} \times 0.5^{\circ}$; approximately $50 \mathrm{~km} \times 50 \mathrm{~km}$ downloaded using the Earth System Grid Federation (ESGF) nodes such as http://esgfnode.dkrz.de/, afterthen; the climate data operator (Schuzweida, 2019), used to processs the monthly data and downscaled it for the specific latitlue and longitude of Hurgada city. These data include the monthly minimum and average relative humidity, maximum and average temperature, sunshine duration, rainfall and wind speed, which essential based on previous TCI research work (Mieczkowski, 1985; Perch-Nielsen et al., 2010). All datasets used to calculate TCI for the different three periods (1952-1975), (1976-2005) and the near future period (2021-2050) are listed in Table 1.

\section{Tourism Climate Index:}

As listed in Bakhtiari et al., (2013) several indicators have been developed to determine the suitability of climatic conditions for the practice of tourism activities over the past 40 years (Mieczkowski, 1985; Freitas, 1990; Becker, 1998; Morgan et al., 2000; Maddison, 2001; Lise \& Tol, 2002; Hamilton \& Lau, 2005; Bigano et al., 2006). The most widely used is the tourism climate index (TCI). Mieczkowski (1985) devised the initial tourism climate index. In total 12 climate variables were identified but because of limitations of meteorological data, the number of climate variables was decreased to seven and put together in five sub-indices (Mieczkowski, 1985).

Tourism Climate Index (TCI) contains seven variables based on mean monthly data (maximum daily temperature, mean daily temperature, minimum daily relative humidity, mean daily relative humidity, total precipitation, total hours of sunshine, and average wind speed). These climate variables were grouped into five sub-indices (three of which are separate and two in a bioclimatic composition). Mieczkowski then weighted the seven variables according to their relative effect on tourist comfort (Table 2).

The highest weight is given to the daytime comfort index to confirm that tourists are more active in general during the day; the next highest weight is given to sunshine and precipitation followed by daily comfort and wind speed.

Table 2. Components of Mieczkowski's (1985) tourism climate index (TCI)

(Source: Mieczkowski, 1985)

\begin{tabular}{|c|c|c|c|c|}
\hline Abbrev & Sub-index & Monthly climate variables & Influence on TCI & Weight (\%) \\
\hline CID & $\begin{array}{c}\text { Daytime } \\
\text { comfort }\end{array}$ & $\begin{array}{c}\text { Max. daily temperature and } \\
\text { min. daily relative humidity }\end{array}$ & $\begin{array}{c}\text { thermal comfort when tourists } \\
\text { have the maximum activity }\end{array}$ & 40 \\
\hline CIA & $\begin{array}{c}\text { Daily } \\
\text { comfort }\end{array}$ & $\begin{array}{c}\text { Mean daily temperature and } \\
\text { mean daily relative humidity }\end{array}$ & $\begin{array}{c}\text { thermal comfort during a day } \\
\text { inaddition to sleeping time }\end{array}$ & 10 \\
\hline P & precipitation & Total precipitation & Negative impact of precipitation & 20 \\
\hline S & sunshine & Total hours of sunshine & $\begin{array}{c}\text { For Tourism is assessed positive and } \\
\text { in the hot days has negative influences }\end{array}$ & 20 \\
\hline W & wind & Average wind speed & $\begin{array}{c}\text { Its effect depends on the temperature } \\
\text { element (positive in hot climates and } \\
\text { negative in cold climates) }\end{array}$ & 10 \\
\hline
\end{tabular}

The final score of tourism climate is produced from the sum of the coefficients for the five sub-indices and it is between o and 100 (Table 3) (Hosseini et al., 2015). Because of a weighting factor (a value for TCI of 100), A classification rating system, ranging among o (very unfavorable) to 5 (ideal), was designed to supply a common basis of 
measurement for each of the sub-indices (Abegg, 1996; Mieczkowski, 1985). The given mathematical equation by Miecakowski estimates the TCI after the determination of the five previous sub-indices values: $\quad \mathrm{TCI}=8 * \mathrm{CID}+2{ }^{*} \mathrm{CIA}+4 * \mathrm{P}+4{ }^{*} \mathrm{~S}+2{ }^{*} \mathrm{~W}$

where CID: Comfort Index Daytime, CIA: Comfort Index dAily, P: Precipitation (mm), S: daily Sunshine duration (hours), and W: mean Wind speed (km/s).

In order to calculate the daytime comfort index (CID) and daily comfort index (CIA) we used thermal comfort assessment charts (Mieczkowski, 1985).

Table 3. Rating categories in the Mieczkowski (1985)

Tourism Climate Index (TCI) (Source: Mieczkowski, 1985)

\begin{tabular}{|l|l|}
\hline TCI score & Descriptive category \\
\hline $90-100$ & ideal \\
\hline $80-89$ & excellent \\
\hline $70-79$ & Very good \\
\hline $60-69$ & Good \\
\hline $50-59$ & Acceptable \\
\hline $40-49$ & Marginal \\
\hline $30-39$ & unfavorable \\
\hline $20-29$ & Very unfavorable \\
\hline $10-19$ & Extremely unfavorable \\
\hline $0-9$ & impossible \\
\hline
\end{tabular}

Precipitation (P): To calculate precipitation we use Table 4 to determine its coefficient. Rainfall is a negative factor in the tourism climate so the coefficient 5 is ideals and toward zero is extremely unfavorable (Table 4).

Sunshine (S): To calculate the coefficient of sunshine, we use Table 4. Sunshine in the tourism climate is a positive factor, but it must take into account the seriousness of the hot days that is unsuitable for tourism (Table 4).

Table 4. Ranking of Precipitation and Sunshine duration Indicators (Source: Mieczkowski, 1985)

\begin{tabular}{|c|c|}
\hline $\begin{array}{c}\text { Total monthly } \\
\text { precipitation }\end{array}$ & $\begin{array}{c}\text { Rating of } \\
\text { precipitation }\end{array}$ \\
\hline 14.9 to 0 & 5 \\
\hline 29.9 to 15 & 4.5 \\
\hline 44.9 to 30 & 4 \\
\hline 59.9 to 45 & 3.5 \\
\hline 74.9 to 60 & 3 \\
\hline 89.9 to 75 & 2.5 \\
\hline 104.9 to 90 & 2 \\
\hline 119.9 to 105 & 1.5 \\
\hline 134.9 to 120 & 1 \\
\hline 149.9 to 135 & 0.5 \\
\hline 150 or more & 0 \\
\hline
\end{tabular}

\begin{tabular}{|c|c|}
\hline $\begin{array}{c}\text { Daily } \\
\text { Sunshine }\end{array}$ & $\begin{array}{c}\text { Rating of } \\
\text { Sunshine }\end{array}$ \\
\hline 10 hour or more & 5 \\
\hline 9.95 to 9 & 4.5 \\
\hline 8.95 to 8 & 4 \\
\hline 7.95 to 7 & 3.5 \\
\hline 6.95 to 6 & 3 \\
\hline 5.95 to 5 & 2.5 \\
\hline 4.95 to 4 & 2 \\
\hline 3.95 to 3 & 1.5 \\
\hline 2.95 to 2 & 1 \\
\hline 1.95 to 1 & 0.5 \\
\hline Less than one hour & 0 \\
\hline
\end{tabular}

Wind (W): Wind is a positive factor for tourism climate. To calculate coefficient of wind Climate type must be determined based on the maximum air temperature level.

For normal system, the maximum temperature must be between 15 and $24^{\circ} \mathrm{C}$, Elyse system (between 24 and $33^{\circ} \mathrm{C}$ ) and the warm climate system is above $33^{\circ} \mathrm{C}$. After determining, we apply Table 5 to determine the final coefficient.

At last, after Determination the coefficient for each indicator, the last indicator (TCI) is calculated from equation (1), which is already mentioned above. 
Table 5. Ranking the wind speed indicator (Source: Mieczkowski, 1985)

\begin{tabular}{|l|c|c|c|}
\hline \multicolumn{1}{|c|}{ Wind speed in $\mathrm{km} / \mathrm{h}$} & Normal system & Elyse system & Warm climate system \\
\hline Less than 2.88 & 5 & 2 & 2 \\
\hline 5.75 to 2.88 & 4.5 & 2.5 & 1.5 \\
\hline 9.03 to 5.76 & 4 & 3 & 0.5 \\
\hline 12.23 to 9.04 & 3.5 & 4 & 0 \\
\hline 19.79 to 12.24 & 3 & 5 & 0 \\
\hline 24.29 to 19.80 & 2.5 & 4 & 0 \\
\hline 28.79 to 24.30 & 2 & 3 & 0 \\
\hline 38.52 to 28.80 & 1 & 2 & 0 \\
\hline More than 38.52 & 0 & 0 & 0 \\
\hline
\end{tabular}

\section{RESULTS AND DISCUSSIONS \\ Results}

The nature of the climate in the city of Hurghada allows tourists to visit and enjoy leisure activities throughout the year as the climate is moderate in most months of the year. The best times to visit the city of Hurghada are the spring and autumn seasons when the peak tourist period is; this is confirmed by the calculation of the Tourism Climate Index for the period 1952-1975 (Table 6). This reveals that the seasons of spring (March, April, May) and autumn (September, October, and November) have high priority for the comfortable climate of tourism followed by the winter season then the summer season.

While climate change and temperatures increase have changed the climatic seasons of tourism as demonstrated by the application of the Tourism Climate Index for the period 1976-2005 and future periods (2021-2050) according to climate change scenarios RCP4.5, RCP8.5 (Figure 3). This is illustrated by the detailed results of the implementation of the Tourism Climate Index for the specified periods as follows.

Table 6. Scores and descriptive values for TCI

\begin{tabular}{|c|c|c|c|c|c|c|c|c|}
\hline Month & \multicolumn{7}{|c|}{ TCI Scores and Descriptive Values } \\
\hline & \multicolumn{2}{|c|}{$1952-1975$} & \multicolumn{2}{|c|}{$1976-2005$} & $2021-2050$ & (RCP45) & 2021-2050 (RCP85) \\
\hline Jan & 87 & Excellent & 87 & Excellent & 88 & Excellent & 90 & Ideal \\
\hline Feb & 89 & Excellent & 89 & Excellent & 92 & Ideal & 92 & Ideal \\
\hline Mar & 93 & Ideal & 96 & Ideal & 100 & Ideal & 100 & Ideal \\
\hline Apr & 98 & Ideal & 90 & Ideal & 92 & Ideal & 92 & Ideal \\
\hline May & 88 & Excellent & 74 & very good & 64 & Good & 64 & Good \\
\hline Jun & 86 & Excellent & 64 & Good & 62 & Good & 54 & acceptable \\
\hline Jul & 70 & very good & 62 & Good & 52 & acceptable & 52 & acceptable \\
\hline Aug & 70 & very good & 62 & Good & 52 & acceptable & 44 & Margin \\
\hline Sep & 86 & Excellent & 72 & very good & 62 & Good & 52 & acceptable \\
\hline Oct & 88 & Excellent & 80 & Excellent & 80 & Excellent & 80 & Excellent \\
\hline Nov & 98 & Ideal & 96 & Ideal & 98 & Ideal & 98 & Ideal \\
\hline Dec & 89 & Excellent & 89 & Excellent & 90 & Ideal & 90 & Ideal \\
\hline
\end{tabular}

\section{TCI scores for the period $1952-1975$}

The results of the tourism climate index for this period can be classified into three categories, which are ideal, excellent and very good. The very best conditions for tourism occurred in April, November and March months, which have 'ideal' rating in TCI descriptive category (TCI: 98, 98, 96) respectively. These are followed by the months of February, December October, May, January, September, and June ('excellent,' TCI: $89,89,88,88.87,86$ ) respectively, then July and August months had the least favorable climate classification for tourism ('very good,' TCI:70). 


\section{TCI scores for the period 1976-2005}

The results of the TCI index for that period have expanded to include a lower rating category than the previous period ('good' rating). November, March, and April months had a TCI scores above 90, ratings that describe an 'ideal' tourism climate. These are followed by the excellent rating category $(90<\mathrm{TCI}>80)$, which its number of months declined two months to take the classification of the following category compared to the previous period to include the months of December, February, January, and October. The climate of May and September was rated 'very good' (TCI: 74, 72) according to the suitability of tourism. The lowest category ('good' rating) in this period was for the summer months (June, July, and August), which is the new category that has emerged, indicating the impact of increases in temperatures as compared to the previous period.

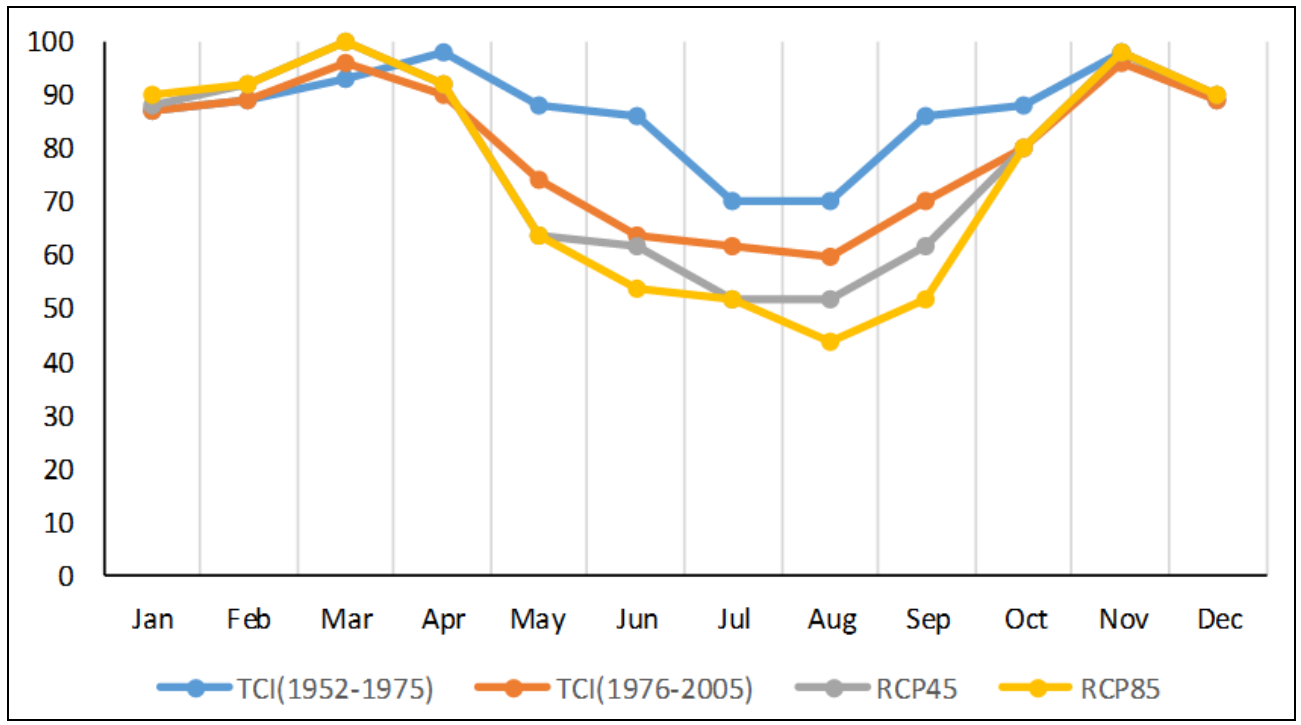

Figure 3. Monthly tourism comfort climate of Hurghada

\section{TCI scores for the period $2021-2050$ (RCP4.5)}

In this period the data is calculated according to Representative Concentration Pathway 4.5 (RCP4.5); TCI refers to the increase in the climatic discomfort for tourism in the summer months, when the rating is reduced to accept a new category ('acceptable' rating) for the month of August and July (TCI: 52). The months of June, September, and May had a 'good' rating, while the values of the climate index for the rest of the months increased. January and October had 'excellent' rating and the months of March, November, April, February, and December had the highest rating category ('ideal'). It should be noted that March has the highest rating for suitability to tourism (TCI: 100).

\section{TCI scores for the period 2021-2050 (RCP8.5)}

The RCP 8.5 pathway was followed in calculation the required data to apply the tourist climate index for this period. The results showed that the lowest month according to the tourist attraction index is August, which was rated 'marginal'(TCI:44), followed by September, July, and June which had 'acceptable' in rating (TCI:52,52,54). This indicates that the summer period is the least attractive for tourism in the year. The month of October still has an 'excellent' rating (TCI: 80), while the remaining months have the highest rating ('ideal,' TCI>90), indicating the attractiveness of the winter season for the entire tourism and spring (March and April). 


\section{Discussion}

As a result of climate change and the impacts of increased temprtaures the city of Hurghada as a tourism destination is expected to face changes in its climatic suitability for tourism in particular during peak periods. This is confirmed by study of the historical situation for the values of the tourist climate index for the periods (1952 to 1975) and (1976-2005), where it was the best months to visit in Spring season (March, April and May) and autumn (September, October, and November). This was confirmed by TCI calculations for the period (1952-1975). By comparison with TCI calculations for the period (1976-2005), it was found that the attractiveness of the climate for tourism for the months of the spring season was reduced according to TCI results, with May moving from the excellent category (TCI 88) to very good (TCI: 74). Also for the months of autumn season, September has moved from the category of excellent (TCI: 86) to the category very good (TCI: 72). As for the summer, the climatic suitability for July, and August were reduced from the very good category (TCI: 70) to the good category (TCI: 62). Winter season kept the same categories of TCI ratings, even though the values have been reduced in some months but retain their category (ideal, excellent).

As shown in (Figure 4) which describes TCI values and tourism season paterns for Hurghada, In the future, according to TCI calculations based on Representative Concentration Pathway 4.5,8.5 climate change and high temperatures are expected to play a major role in increasing the period of unsuitable climatic for tourism at the expense of the traditional peak periods for Hurghada tourism. The climatic suitability for tourism has decreased for certain months (September, June, and May) to join the summer months (July and August) as the least attractive for tourism throughout the year.

While it was noted that the positive effects of the expected future climate change according to TCI calculations based on Representative Concentration Pathway 4.5,8.5 were observed in the rest of the months, which increased the attractiveness of their tourism climate, where March had the highest rating (ideal TCI: 100). The months of December, January, and February (the winter season) took on an 'ideal' category (TCI> 90) and April (spring season) was rated 'ideal' (TCI: 92), as well as November had 'ideal' category (TCI: 98). While it was noted that the rest of the months increased the attractiveness of its climate of tourism, where March had the highest rating (ideal TCI: 100). The months of December, January, and February (the winter season) took on an 'ideal' category (TCI> 90) and April (spring season) was rated 'ideal' (TCI: 92), as well as November had 'ideal' category (TCI: 98 ).

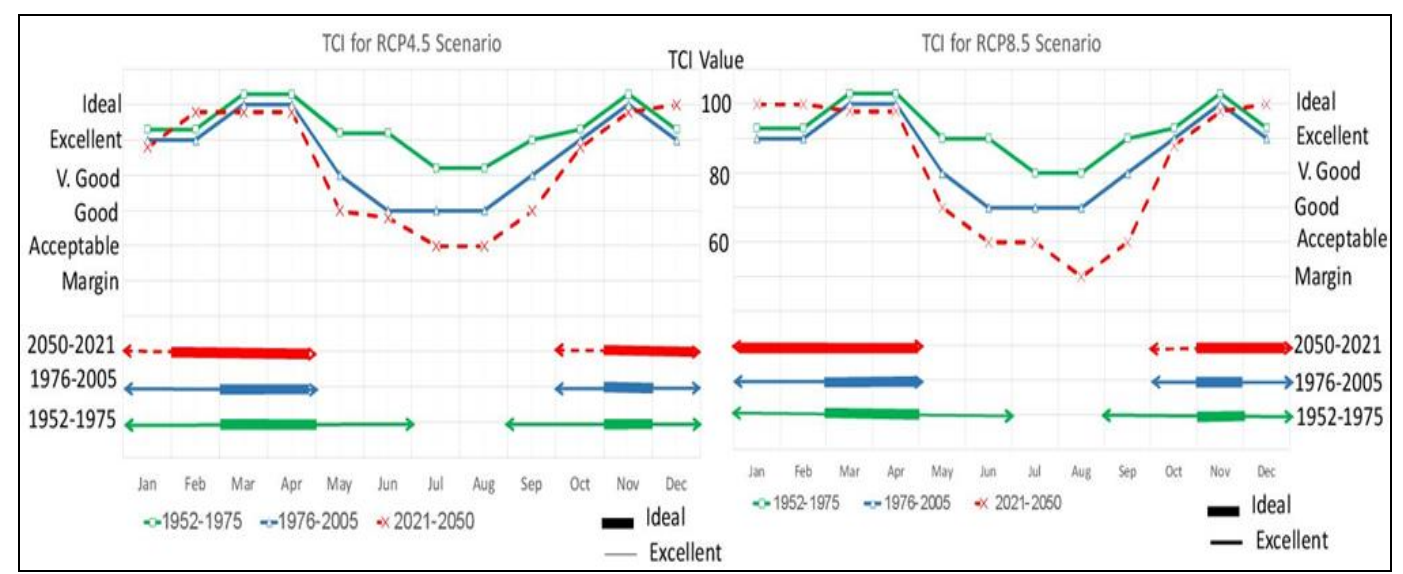

Figure 4. Hurghada TCI tourism seasons pattren analysis 


\section{CONCLUSION}

Prediction and study of the expected impacts of climate change, whether positive or negative, using mean and maximum values, is important in the planning and management of tourism areas in order to absorb the negative effects and take advantage of the positive opportunities resulting from those effects. The research highlights the resreach methodology, which can be summarized in (Figure 5), for the asessment of the effects of climate change phenomena on the future of tourism sector.

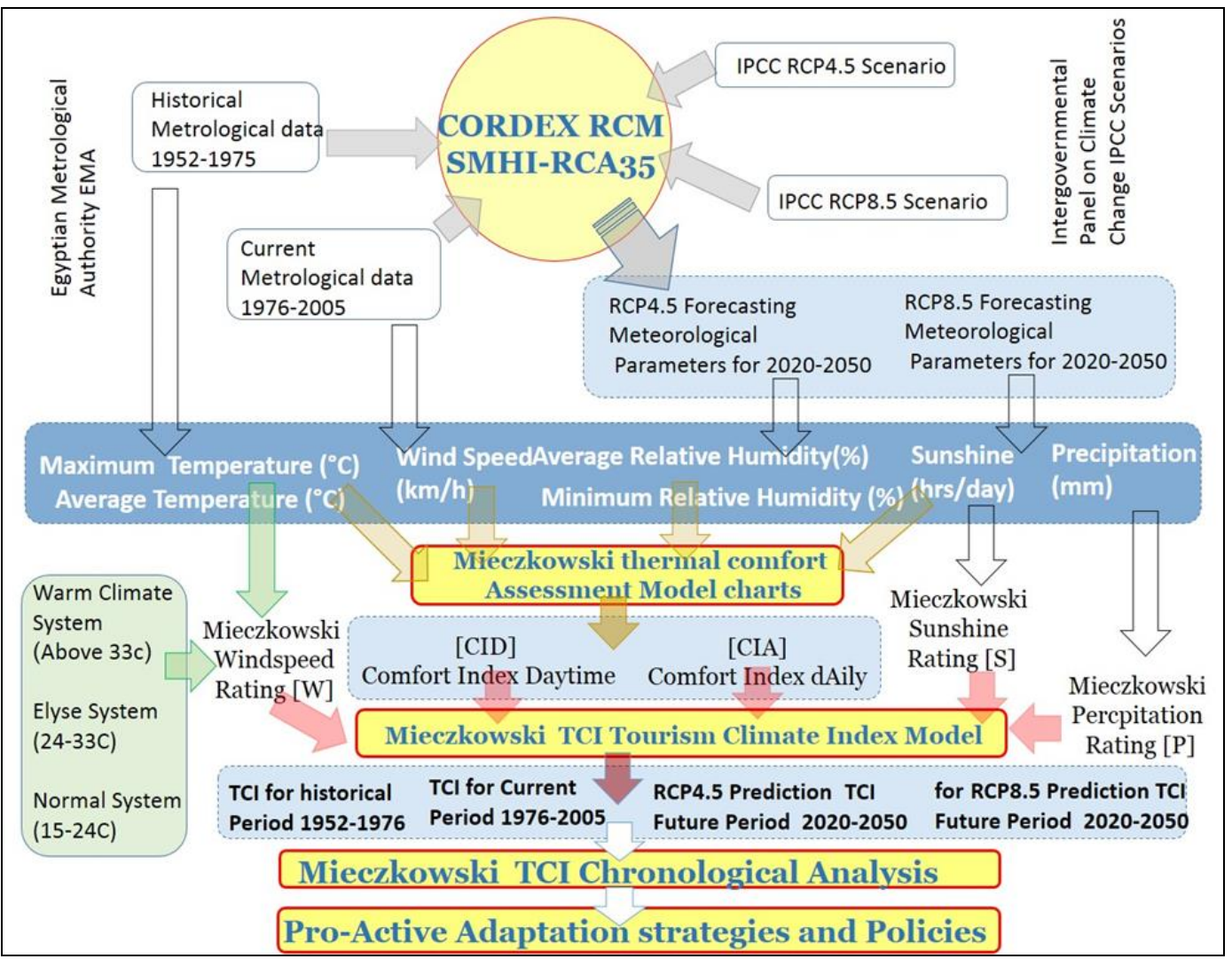

Figure 5. Research methodolody for climate change impacts on tourism

The Tourism Climate Index (TCI) is a useful indicator that combines several variables and presents them in the form of an indicator that facilitates tourism planners and marketing agents to plan and manage tourism by anticipating off-peak periods to develop tourism promotion programs for that period, and expect busy peak times to identify the development programs required to meet them. In addition tourists can take advantage of climate indicators to select the best tourist destinations and the timing of their vacation. The city of Hurghada is dependent on tourism activity in its economy; therefore, considering climatic changes and high temperatures, prediction and study of the expected impacts of climate change is important for the planning and management of the tourism sector in it. According to the results of the application of the TCI index on its climate, it is expected that the seasons of tourism will be changed according to both RCP4.5 (stability scenario) and RCP8.5 (Scenario with very high greenhouse gas emissions). Overall, it was found that the period from May to September is the least 
suitable period for tourism according to both of them and the lowest estimate is the month of August (TCI:44). Arguably, it is necessary to plan and develop infrastructure and architectural design to faciliate activities that are appropriate for the climate of that period as well as promoting them to maintain the local economy. Correspondingly, as March becames the most attractive climate for tourism (TCI: 100) followed by November (TCI: 98), April, February (TCI:92), December and January (TCI :90), it is essential to promote this period through the development of appropriate entertainment programs. In addition, planning and infrastructure development of the city is essential to accommodate this period which becomes the peak tourism season. These are local responses required to address the challenges as well as opportunities resulting from climate change.

\section{Aknowlegments}

The authors are grateful to CORDEX Africa for providing model data used in this study. This study would not have been possible without the access to valuable monthly dataset from the Egyptain Meteorological Authoristy.

\section{REFERENCES}

Abegg, B. (1996). Klimaänderung und Tourismus. Schlussbericht NFP 31. vdf Hochschulverlag AG an der ETH, Zürich. Bakhtiari, B., Bakhtiari, A., \& Afzali Gorouh, Z. (2018), Investigation of climate change impacts on tourism climate comfort in Iran. Global NEST Journal, 20(X), XX-XX.

Bakhtiari, B., \& Bakhtiari, A. (2013). Determination of tourism climate index in Kerman province. DESERT, 18, 113-126.

Becker, S. (1998). Beach comfort index: a new approach to evaluate the thermal conditions of beach holiday resort using a South Africa example. Geojournal, 44(4), 297-307.

Behaylu, A., Teshome, G. ( 2018). Seasonal Analysis Using Tourism Climate Index of Major Tourist Places of Ethiopia. IOSR Journal Of Humanities And Social Science (IOSR-JHSS) Volume 23, Issue 11, Ver. 3.

Bigano, A., Hamilton, J.M., \& Tol, R.S.J. (2006). The impact of climate on holiday destination choice. Clim Chang, 76(3-4), 389-406.

Cantin, N.E., Cohen, A.L., Karnauskas, K.B., Tarrant, A.M., \& McCorkle, D.C. (2010). Ocean warming slows coral growth in the central Red Sea. Science, 329:322-325.

De Freitas, C.R. (1990). Recreation climate assessment. International Journal of Climatology, 10: 89-103.

De Freitas, C.R., Scott, D., \& McBoyle, G. (2008). A second generation climate index for tourism (CIT): specification and verification. International Journal of Biometeorology, 52, 399-207.

Fang, Y., \& Yin, J. (2015). National Assessment of Climate Resources for Tourism Seasonality in China Using the Tourism Climate Index. Atmosphere, 6, 183-194.

Farajzadeh, H., \& Matzarakis, A. (2009). Quantification of climate for tourism in the northwest of Iran. Meteorological Applications, 16, 545-555.

Gandomkar, A., Mohseni, N., \& Branch, N. (2011). Analysis and Estimate Tourism Climate Index of Mazandaran Province. Using TCI Model, 2nd International Conference on Business, Economics and Tourism Management IPEDR vol.24, IACSIT Press, Singapore.

Giorgi, F., Jones, C., \& Asrar, G.R. (2009). Addressing climate information needs at the regional level: The CORDEX framework. WMO Bull, 58, 175-183.

Gomez Martin, M.B. (2005). Weather, climate and tourism. A Geographical Perspective. Annals of Tourism Research, 32(3), 571-591.

Gonzalez, P.L.M., \& Goddard, L. (2016). Long-lead ENSO predictability from CMIP5 decadal hindcasts. Clim. Dyn., 46, 3127-3147.

Gourabi, B.R., \& Palic. M. (2012). Recognition of Monthly human bioclimatic comfort with tourism climate index in Ramsar, South-West of Caspian sea, Iran Acta Geographica Debrecina: Landscape and Environment Series, 6 (1).

Hamilton, J., \& Lau, M. (2005). The role of climate information in tourist destination choice decision-making. In Gössling, S., Hall, C.M. (Eds.) Tourism and global environmental change. Routledge, London, p. 229-250.

Hosseini, M.I., \& Jahanbin, N. (2015). Evaluating the Time Distribution of Tourism Climate of Kerman Using TCI Model. Science Arena Publications, 33-42.

Jones, C., Giorgi, F., \& Asrar, G. (2011). The coordinated regional downscaling experiment CORDEX: An international downscaling link to CMIP5. CLIVAR Exchanges, 16(2), 34-40.

Kubokawa, H., Inoue, T., \& Satoh , M. ( 2014). Evaluation of the Tourism Climate Index over Japan in a Future Climate Using a Statistical Downscaling Method. Journal of the Meteorological Society of Japan, Vol. 92, No. 1, p. 37-54. 
Lise, W., \& Tol, R.S.J. (2002). Impact of climate on tourist demand. Clim. Chang, 55(4), 429-449.

Maddison, D. (2001). In search of warmer climates? The impact of climate change on flows of British tourists. Clim. Chang., 49, 193-208.

Meehl, G.A., Teng, H., \& Arblaster, J.M. (2014). Climate model simulations of the observed early-20oos hiatus of global warming. Nat. Clim. Chang., 4, 898-902.

Mieczkowski, Z. (1985). The tourism climatic index: a method of evaluating world climates for tourism. Canadian Geographer, 29, 220-233.

Morgan, R., Gatell, E., Junyent, R., Micallef, A., Özhan, E., \& Williams, A. (200o). An improved user-based beach climate index. Journal of Coastal Conservation, 6, 41-50.

Moss, R. H., Edmonds, J. A., Hibbard, K. A., Manning, M. R., Rose, S. K., Van Vuuren, D. P., ... \& Meehl, G. A. (2010). The next generation of scenarios for climate change research and assessment. Nature, 463, 747-756.

Moss, R., Babiker, W., Brinkman, S., Calvo, E., Carter, T., Edmonds, J., ... \& Jones, R. N. (2008). Towards new scenarios for the analysis of emissions: Climate change, impacts and response strategies. Intergovernmental Panel on Climate Change, Geneva, p. 132.

Németh, A. (2013). Estimation of Tourism Climate in the lake Balaton region, Hungary. Journal of Environmental Geography, 6, 49-55.

Pachauri, R.K., Allen, M.R., Barros, V.R., Broome, J., Cramer, W., Christ, R., Church, J.A., Clarke, L., Dahe, Q., \& Dasgupta, P. (2014). Climate change 2014: synthesis report. Contribution of Working Groups I, II and III to the fifth assessment report of the Intergovernmental Panel on Climate Change, IPCC.

Perch-Nielsen, S.L., Amelung, B., \& Knutti, R. (2010). Future climate resources for tourism in Europe based on the daily tourism climate index. Clim. Chang, 103, 363-381.

Roshan, G., Yousefi, R., \& Fitchett, J. M. (2016). Long-term trends in tourism climate index scores for 40 stations across Iran: the role of climate change and influence on tourism Sustainability. International journal of biometeorology, 6o, 33-52.

Rossello-Nadal, J., (2014). How to evaluate the effects of climate change on tourism. Tourism Management, 42, 334-340.

Samuelsson, P., Jones, C.G., Willén, U., Ullerstig, A., Gollvik, S., Hansson, U., Jansson, C., Kjellström, E., Nikulin, G., \& Wyser, K . (2011). The Rossby Centre regional climate model RCA3: model description and performance. Tellus, 63, 4-23.

Schulzweida, U. (2019). CDO User Guide (version 1.9.6). http://doi.org/10.5281/zeodo.2558193.

Scott, D., McBoyle, G., \& Schwartzentruber, M. (2004). climate change and the distribution of climate resources for tourism in North America. Climate Research, 27, 105-117.

Smith, J, Deck, L., McCarl, B., Kirshen, P., Malley, J., \& Abdrabo, M. (2013). Potential Impacts of Climate Change on the Egyptian Economy, A Report Prepared for the United Nations Development Program (UNDP). Cairo, Egypt, p. 143.

Solomon, S., Qin, D., Manning, M., Chen, Z., Marquis, M., Averyt, K. B., Tignor M., Miller H. L., (des.), (2007). Contribution of working group I to the fourth assessment report of the intergovernmental panel on climate change. Cambridge, United Kingdom and New York:Cambridge University Press.

Stocker, T.F., Qin, D., Plattner, G.K., Tignor, M., Allen, S.K., Boschung, J., Nauels, A., Xia, Y., Bex, V., \& Midgley, P.M. (2013). Climate Change 2013 The Physical Science Basis. Switzerland: IPCC.

Van-Vuuren, D.P., Edmonds, J., Kainuma, M., Riahi, K., Thomson, A., Hibbard, K., \& Masui, T. (2011). The representative concentration pathways: an overview. Climatic change, 109 (1-2), 5 .

Taylor, K.E., Stouffer, R.J., \& Meehl, G.A. (2012). An overview of CMIP5 and the experiment design. Bull. Am. Meteor. Soc., 93, 485-498.

Tolba, M.K., Allam, M., Sabry, E, Labib , M.W., Mohamed, Y.S., ... \& Ahmed, C.A. (2016). Egypt Third National Communication. cairo: Egyptian Environmental Affairs Agency.

*** CAPMAS. (2017). Annual Bulletin of Tourism Statistics 2016. Cairo: CAPMAS.

*** CAPMAS - Ministry of Tourism. (2018). Statistical Yearbook - Tourism. Cairo: Ministry of Tourism.

*** IPCC. (2013). Climate Change 2013: The Physical Science Basis. Contribution of Working Group I to the Fifth Assessment Report of the Intergovernmental Panel on Climate Change [Stocker, T.F., Qin, D., Plattner, G.K., Tignor, M., Allen, S.K., Boschung, J., Nauels, A., Xia, Y., Bex, V., Midgley, P.M. (eds.)]. Cambridge University Press, Cambridge, United Kingdom and New York, NY, USA, 1535 pp., doi:10.1017/CBO9781107415324.

*** WTTC. (2017). Travel \& Tourism Economic Impact Egypt 2017. London: the World Travel \& Tourism Council.

https://www.emaeg.org/?lang=en, accessed requested data 04.01.2019.

http://esgf-node.dkrz.de/, accessed 04.01.2019.

https://www.mfa.gov.eg/english/InsideEgypt/Pages/Tourism.aspx, accessed 13.01.2019.

http://www.sis.gov.eg/section/415/440?lang=en-us, accessed 13.01.2019.

http://www.egypt.travel/en/regions/red-sea/hurghada-city, accessed 13.01.2019.

Submitted:

17.02.2019
Revised:

16.05.2019
Accepted and published online 10.06.2019 